\title{
Meta-Analysis to Determine Normative Values for the Special Judo Fitness Test in Male Athletes: 20+ Years of Sport-Specific Data and the Lasting Legacy of Stanisław Sterkowicz
}

\author{
Katarzyna Sterkowicz-Przybycien ${ }^{1}$, David H. Fukuda ${ }^{2, *(1)}$ and Emerson Franchini ${ }^{3}(\mathbb{D}$ \\ 1 Department of Gymnastics and Dance, Institute of Sport Sciences, University of Physical Education, \\ 31-571 Krakow, Poland \\ 2 School of Kinesiology and Physical Therapy, Institute of Exercise Physiology and Rehabilitation Science, \\ University of Central Florida, Orlando, FL 32816, USA \\ 3 Martial Arts and Combat Sports Research Group, Sport Department, School of Physical Education and Sport, \\ University of Sao Paulo, Sao Paulo 05508-030, Brazil \\ * Correspondence: david.fukuda@ucf.edu
}

Received: 10 June 2019; Accepted: 9 August 2019; Published: 16 August 2019

check for updates

\begin{abstract}
The aim of this study was to evaluate Special Judo Fitness Test (SJFT) results specific to the population of male judoka and to develop age category norms for junior and senior athletes. A systematic review of the existing literature was conducted to identify 281 publications reporting SJFT results between 1995 and 2018. The final meta-analysis included data from 37 relevant studies that reported SJFT results from 51 individual samples of 515 senior and 209 junior male athletes. The combined mean and SD for SJFT variables were calculated, and the Cohen's d effect size with 95\% confidence intervals (CI) for the senior and junior age classifications were compared. Senior athletes demonstrated higher total number of throws $(d=0.41, \mathrm{CI}=0.25-0.57, p<0.001)$ and heart rate (HR) immediately after the SJFT $(d=0.18, \mathrm{CI}=0.02-0.35, p=0.025)$ with limited differences for HR one minute after the SJFT between groups. The SJFT index was lower for seniors compared to juniors $(d=$ $0.38, \mathrm{CI}=0.22-0.54, p<0.001$ ) indicating better overall performance by the more advanced athletes. Percentile rankings were used to develop SJFT classificatory tables for male senior and junior judo athletes. Training staff can use the age group classifications in the evaluation process of their athletes and for the purpose of monitoring training.
\end{abstract}

Keywords: martial arts; systematic review; athletic performance; age groups

\section{Introduction}

The assessment and evaluation of athletes has evolved to include comprehensive monitoring programs consisting of both general and sport-specific testing. In an effort to simulate the high-intensity intermittent nature of the Olympic sport of judo, a variety of sport-specific tests have been developed that mimic both the technical-tactical actions and energy systems utilized during competition or training [1-4]. Originally devised by the late Stanisław Sterkowicz in 1995, the Special Judo Fitness Test (SJFT) is now the most popular and well-researched of these assessments [5]. The SJFT meets the desired criteria of objectivity, reliability and validity [6], as confirmed by a large number publications examining the physical preparation of judo athletes [1,7-9]. Furthermore, strong correlations support the sensitivity and potential usefulness of this tool in the areas of physiology $[7,10]$, biomechanics [11], and psychology [12]. The ecological utility of the SJFT, including the ability to perform within the training environment, rather than in a laboratory setting, and its relative simplicity represent an 
efficacious methodology for the periodic monitoring and sport-specific evaluation of judo athletes. In 2010, the SJFT was recommended by the Polish Ministry of Sport and Tourism for regular assessment of athletes in clubs as well as the national team [13].

The SJFT is divided into three periods $(\mathrm{A}=15 \mathrm{~s} ; \mathrm{B}$ and $\mathrm{C}=30 \mathrm{~s})$ separated by 10 -s intervals of passive rest. During each period, the athlete being evaluated sprints between and throws each of the two partners of similar height and body mass using the one-armed shoulder throw (ippon-seoi-nage) as many times as possible. The athlete begins the test placed $3 \mathrm{~m}$ from each partner. Immediately following and one minute after the test, heart rate is measured. Stopwatches and heart rate monitors can be employed to aid in the testing procedures [14]. The SJFT index is calculated as follows:

$$
\text { SJFT Index }=\frac{\text { Final HR }(\text { bpm })+H R 1 \min (b p m)}{\text { Throws }(N)}
$$

where Final HR is the heart rate recorded immediately after the test; HR $1 \mathrm{~min}$ is the heart rate obtained $1 \mathrm{~min}$ after test; and Throws is the number of throws completed during the test. Within this context, lower SJFT Index values are indicative of superior fitness and sport-specific performance. Visualization of the Special Judo Fitness Test is available on the Internet [15].

With this unique approach, the individual variables and resulting index from the SJFT provide insight into several key judo-specific factors, including maximal performance, technical execution, fatigability, and recovery. This insight coupled with the possibility of detecting even small changes in fitness during preparation for competition [16] supports the popularity of SJFT across various demographic characteristics. The SJFT has been used in the examination of numerous situations related to performance, including the effects of rapid weight loss [17], recovery type between matches [9], pre-exercise warm-up strategies [18], long-term training programs [19-23], and laterality [24]. With respect to dietary supplementation, scientific studies have evaluated the effects of creatine malate [25], sodium bicarbonate [26], creatine monohydrate [27], and caffeine ingestion [28] on SJFT performance. A more comprehensive review of the available literature on the topic of the SJFT is presented in the recent book chapter by Sterkowicz-Przybycień et al. [29].

In the absence of available data, the provisional test norms developed for men practicing judo [14] have been used in the evaluation of athletes regardless of sex or age category. Due to the potential miscategorization of women, our original meta-analysis focused on developing normative data for the SJFT in this population [30]. Using this methodology, we synthesized the previously reported findings on an international scale, thereby indicating samples deviating from median values, and established norms for junior and senior women. However, to date, comparable data do not exist for male judoka relative to age categories, and reports on differences in SJFT performance between younger and older athletes are ambiguous [31,32]. Therefore, the main aim of this study was to evaluate the SJFT results specific to the population of professional judoka and to develop age category norms for junior and senior athletes.

\section{Materials and Methods}

A systematic review and meta-analysis of the available literature reporting results from the SJFT was conducted following Preferred Reporting Items for Systematic Reviews and Meta-Analysis [33]. The keywords "judo", "fitness", "special", and "SJFT" were utilized to search relevant publications in the following international databases: SportDiscus with full text, MEDLINE, Web of Science, Academic Search Complete, EBSCOhost, and Google Scholar, and papers cited in the original retrieved investigations were searched manually. The inclusion criteria were: (1) data on the age of study participants; (2) competitive level; (3) reporting of sample size and means and standard deviations (SD) for all four SJFT variables; and (4) male participants. The exclusion criteria were: (1) omission of age data; (2) omission of means and standard deviations for SJFT data; and (3) female participants. Publications from January 1995 through December 2018 were included. After identification in databases, the studies were assessed through title and abstracts. Duplicates and studies that did not meet inclusion 
criteria were excluded. The languages of studies were English, Polish, Russian, and Portuguese, and the data concerned samples of athletes ranging from novice to those at the national or international competitive level. All included study outcomes were complete and not selectively reported. Age categories were determined according to the International Judo Federation senior ( $>21$ years old) and junior ( $\leq 21$ years old) age classifications [34].

The combined means and SD for number of throws completed during the test, the heart rate values immediately after and $1 \mathrm{~min}$ after the test, and the SJFT index were calculated according to equations recommended by Kirkendall et al. [6].

$$
\begin{gathered}
\text { Combined } \bar{x}=\frac{\sum\left(\bar{x}_{i} \cdot n_{i}\right)}{\sum n_{i}} \\
\text { Combined } S D=\sqrt{\frac{\sum\left(n_{i} \cdot S D_{i}^{2}\right)}{\sum n_{i}}}
\end{gathered}
$$

where $\bar{x}_{i}$ is the mean value for a given sample, $n_{i}$ is the sample size for a given sample, and $S D_{i}$ is the standard deviation for a given sample. Subsequently, the Cohen's $d$ effect size with $95 \%$ confidence intervals for the senior and junior age classifications for each of the parameters of SJFT using combined $\bar{x}$ and combined SD was calculated. The following interpretation of Cohen's $d$ effect sizes were employed: small $=0.20$, medium $=0.5$, large $=0.80$ [35]. A random effects meta-analysis was utilized to evaluate the relevant samples for the SJFT Index. To indicate the extent of heterogeneity between individual samples the Cochran $Q$ test and $I^{2}$ statistic (range from $0 \%$ to $100 \%$ ) were computed. The interpretation of $I^{2}$ values was completed as follows: low $\leq 25 \%$, moderate $20-50 \%$, and high $\geq 75 \%$.

Percentile rankings considering a $5^{\circ}$ scale were used to develop SJFT classificatory tables for male senior and junior judo athletes in the following categories: Excellent $=$ highest $5 \%$ or above the 95th percentile, Good $=$ next highest $15 \%$ or between the 80 th and 95 th percentiles, Regular $=$ middle $60 \%$ or between the 20th and 80 th percentiles, Poor $=$ next lowest $15 \%$ or between the 5 th and 20 th percentiles, and Very poor $=$ lowest $5 \%$ or below the 5 th percentile. The statistical calculations were made using the 'metafor' package [36] running under R Environment [37], SPSS 21, and Excel.

\section{Results}

The results of the different phases of the systematic literature search are illustrated in Figure 1. A total of 281 documents were initially identified. During the screening stage, duplicates and ineligible papers were removed. At the eligibility stage, 39 studies that did not meet the inclusion criteria were excluded. The final analysis included data from 37 relevant studies that reported SJFT results from 51 individual samples of 515 senior (Table 1) and 209 junior male judo athletes (Table 2).

The results of the meta-analysis for SJFT Index in the senior $(n=515)$ and junior $(n=209)$ judo athletes are illustrated in Figure 2. High heterogeneity was found for seniors $\left(Q=579.9, p<0.001, I^{2}=\right.$ 94.3), juniors $\left(Q=216.0, p<0.001, I^{2}=92.6\right)$, and the combined subgroups $\left(Q=90.3, p<0.001, I^{2}=94.4\right)$. 


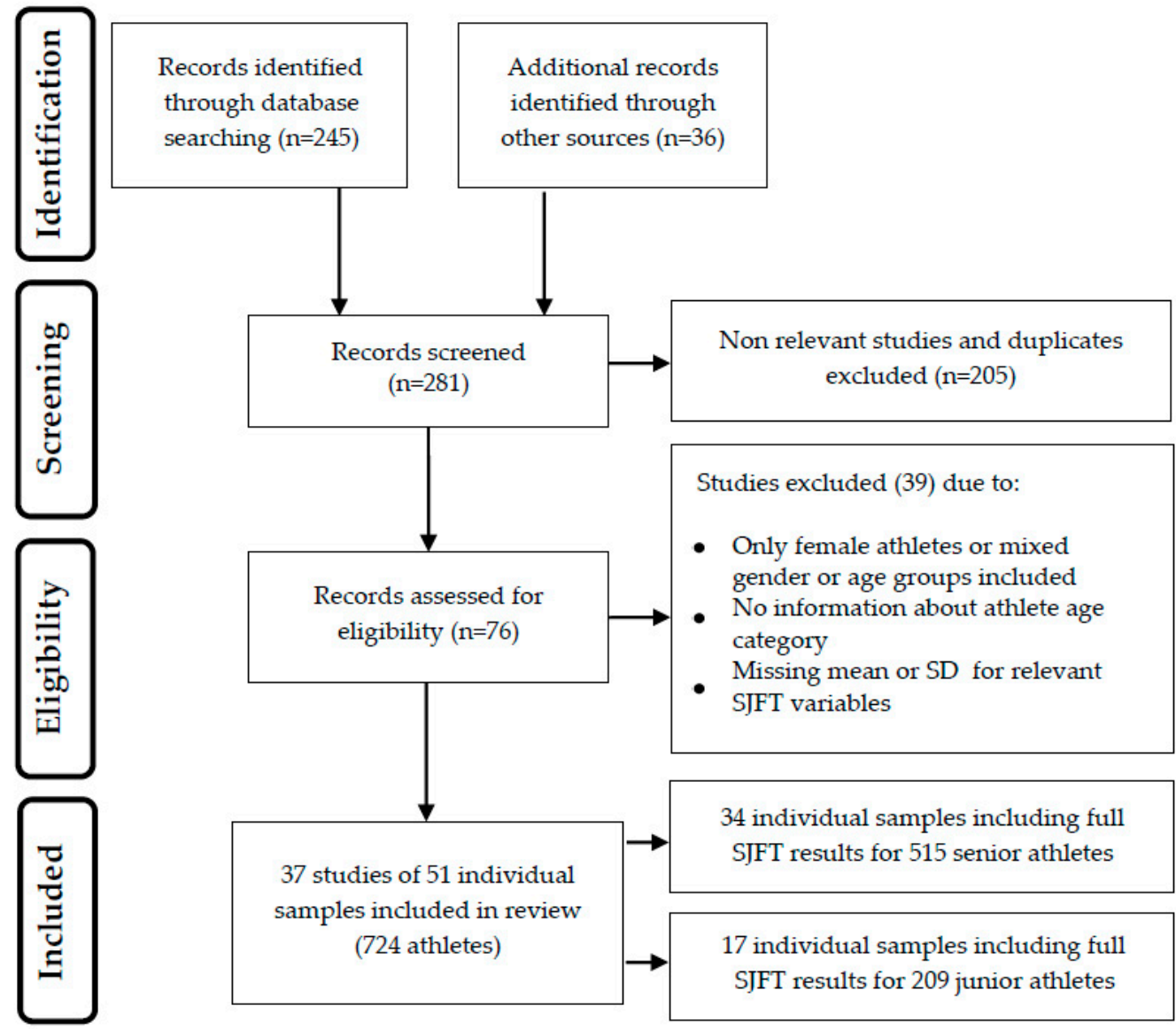

Figure 1. Flow diagram of the literature search procedure. SJFT $=$ Special Judo Fitness Test. 
Table 1. Special Judo Fitness Test (SJFT) results reported in 34 international samples of senior male judo athletes.

\begin{tabular}{|c|c|c|c|c|c|c|c|c|c|c|c|c|c|}
\hline \multirow[b]{2}{*}{ Source } & \multirow[b]{2}{*}{ Study } & \multirow[b]{2}{*}{ Country } & \multirow[b]{2}{*}{ Age Category } & \multirow[b]{2}{*}{ Level } & \multirow[b]{2}{*}{$n$} & \multicolumn{2}{|c|}{ Throws } & \multicolumn{2}{|c|}{ Final HR $\left(b \cdot \min ^{-1}\right)$} & \multicolumn{2}{|c|}{ HR $1 \min \left(b \cdot \min ^{-1}\right)$} & \multicolumn{2}{|c|}{ SJFT Index } \\
\hline & & & & & & $\bar{x}$ & SD & $\bar{x}$ & SD & $\bar{x}$ & SD & $\bar{x}$ & SD \\
\hline Sterkowicz, 1996 [38] & CS & Poland & Senior & $\mathrm{E}$ & 10 & 27.4 & 4.7 & 177 & 9.5 & 130 & 7 & 11.57 & 2.52 \\
\hline Sterkowicz, 1996 [38] & CS & Poland & Senior & $\mathrm{N}$ & 10 & 24 & 2 & 182 & 6.4 & 136 & 4.2 & 13.28 & 1.34 \\
\hline Sterkowicz et al. 1999 [7] & CS & Poland & Senior & $\mathrm{E}+\mathrm{N}$ & 15 & 27.3 & 2.7 & 181.6 & 6.2 & 150 & 11.8 & 12.29 & 1.48 \\
\hline Franchini et al. 2001 [39] & CS & Brazil & Senior & $\mathrm{N}$ & 6 & 24.2 & 1.2 & 179 & 11.4 & 157 & 15.4 & 13.92 & 1.06 \\
\hline Sterkowicz and Franchini 2001 [32] & CS & Brazil and Poland & Senior & E & 33 & 27.7 & 2.9 & 180 & 10 & 152 & 18.1 & 12.1 & 1.6 \\
\hline Sterkowicz and Franchini 2001 [32] & CS & Brazil and Poland & Senior & $\mathrm{N}$ & 47 & 25.1 & 2.2 & 185 & 9.6 & 156 & 15.5 & 13.6 & 1.4 \\
\hline Khakhabrishvili et al. 2003 [40] & CS & Georgia & Senior & $\mathrm{E}$ & 7 & 26.1 & 0.3 & 181 & 0.4 & 156 & 0.4 & 13 & 0.31 \\
\hline Khakhabrishvili et al. 2003 [40] & CS & Poland & Senior & E & 7 & 24.7 & 0.3 & 183 & 0.4 & 160 & 0.6 & 13.85 & 0.14 \\
\hline Sterkowicz et al. 2005 [41] & CS & Germany & Senior & $\mathrm{E}$ & 9 & 29.1 & 2.2 & 183 & 5.1 & 156 & 8.3 & 11.7 & 0.99 \\
\hline Franchini et al. 2005 [8] & CS & Brazil & Senior & $\mathrm{E}$ & 13 & 28.0 & 2 & 179 & 6 & 163 & 10 & 12.28 & 1.01 \\
\hline Franchini et al. 2005 [8] & CS & Brazil & Senior & $\mathrm{E}$ & 23 & 28 & 2 & 181 & 10 & 162 & 12 & 12.53 & 1.11 \\
\hline Franchini et al. 2005 [8] & CS & Brazil & Senior & $\mathrm{N}$ & 53 & 25 & 2 & 186 & 11 & 165 & 13 & 14.16 & 1.52 \\
\hline Franchini et al. 2007 [42] & CS & Brazil & Senior & $\mathrm{E}$ & 7 & 28 & 3 & 178 & 9 & 157 & 11 & 11.83 & 1.16 \\
\hline Franchini et al. 2007 [42] & CS & Brazil & Senior & $\mathrm{E}$ & 13 & 27 & 2 & 175 & 9 & 151 & 7 & 12.21 & 1.26 \\
\hline Da Silva et al. 2008 [43] & CS & Brazil & Senior & $\mathrm{N}$ & 30 & 20.2 & 2.7 & 184 & 3.7 & 139 & 4.2 & 15.94 & 1.78 \\
\hline Radovanović et al. 2008 [27] & CS & Serbia & Senior & $\mathrm{N}$ & 6 & 24.8 & 2.8 & 181 & 6.4 & 155 & 11.8 & 13.95 & 1.82 \\
\hline Radovanović et al. 2008 [27] & P1 & Serbia & Senior & $\mathrm{N}$ & 6 & 24.2 & 2.5 & 183 & 7.8 & 156 & 13.1 & 14.18 & 1.96 \\
\hline Janse de Jonge et al. 2009 [44] & CS & Australia & Senior & $\mathrm{E}$ & 12 & 27.3 & 2.7 & 174 & 10 & 157 & 11 & 12.26 & 1.34 \\
\hline Franchini et al. 2011 [45] & CS & Poland & Senior & $\mathrm{N}$ & 14 & 26 & 2 & 196 & 12 & 169 & 9 & 14.37 & 1.33 \\
\hline Detanico et al. 2012 [46] & CS & Brazil & Senior & $\mathrm{N}$ & 18 & 27 & 2 & 179 & 10 & 155 & 15 & 12.5 & 1.3 \\
\hline Escobar-Molina et al. 2012 [31] & CS & Spain & Senior & $\mathrm{E}$ & 10 & 26 & 2 & 183 & 7 & 160 & 15 & 13.34 & 1.29 \\
\hline Katralli et al. 2012 [47] & CS & India & Senior & $\mathrm{N}$ & 20 & 28.4 & 2.3 & 177 & 9 & 141 & 21.6 & 11.3 & 1.4 \\
\hline Katralli et al. 2012 [47] & CS & India & Senior & $\mathrm{N}$ & 11 & 28.4 & 2 & 181 & 5.7 & 143 & 18.2 & 11.4 & 1 \\
\hline Barreto et al. 2012 [48] & CS & Brazil & Senior & $\mathrm{N}$ & 9 & 21.9 & 2.9 & 183.3 & 12.5 & 161.3 & 20.5 & 16 & 2.6 \\
\hline Hesari et al. 2014 [49] & CS & Iran & Senior & $E+N$ & 19 & 28 & 1.8 & 177 & 6.8 & 143 & 10.5 & 11.7 & 1 \\
\hline Franchini et al. 2015 [20] & $\mathrm{RM}$ & Brazil & Senior & $\mathrm{N}$ & 6 & 25 & 2 & 188 & 10 & 166 & 14 & 14.36 & 1.68 \\
\hline Franchini et al. 2015 [20] & $\mathrm{RM}$ & Brazil & Senior & $\mathrm{N}$ & 7 & 25 & 2 & 177 & 13 & 150 & 17 & 12.98 & 1.4 \\
\hline Sterkowicz-Przybycień et al. 2014 [50] & $\mathrm{RM}$ & Poland & Senior & $\mathrm{N}$ & 7 & 27.9 & 1.8 & 181 & 10.9 & 151.7 & 13.9 & 11.96 & 0.82 \\
\hline Abedelmalek et al. 2015 [17] & $\mathrm{RM}$ & Tunisia & Senior & $\mathrm{N}$ & 11 & 31 & 2.7 & 182.3 & 5.3 & 154 & 2.8 & 10.8 & 3 \\
\hline
\end{tabular}


Table 1. Cont.

\begin{tabular}{|c|c|c|c|c|c|c|c|c|c|c|c|c|c|}
\hline \multirow[b]{2}{*}{ Source } & \multirow[b]{2}{*}{ Study } & \multirow[b]{2}{*}{ Country } & \multirow[b]{2}{*}{ Age Category } & \multirow[b]{2}{*}{ Level } & \multirow[b]{2}{*}{$n$} & \multicolumn{2}{|c|}{ Throws } & \multicolumn{2}{|c|}{ Final HR $\left(b \cdot \min ^{-1}\right)$} & \multicolumn{2}{|c|}{ HR 1 min $\left(b \cdot \min ^{-1}\right)$} & \multicolumn{2}{|c|}{ SJFT Index } \\
\hline & & & & & & $x$ & SD & $x$ & SD & $x$ & SD & $x$ & SD \\
\hline Franchini et al. 2015 [51] & $\mathrm{RM}$ & Brazil & Senior & $\mathrm{N}$ & 10 & 28 & 1 & 197 & 6 & 178 & 9 & 13.66 & 1.04 \\
\hline Sterkowicz-Przybycień et al. 2015 [24] & CS & Poland & Senior & $\mathrm{E}+\mathrm{N}$ & 17 & 28 & 2.4 & 183 & 8.2 & 136 & 11.9 & 11.49 & 1.11 \\
\hline Ohkawa et al. 2015 [52] & CS & Japan & Senior & $\mathrm{N}$ & 24 & 27.2 & 1.9 & 172 & 8.6 & 146 & 12.8 & 11.72 & 1.24 \\
\hline Sogabe et al. 2015 [53] & $\mathrm{RM}$ & Japan & Senior & $\mathrm{N}$ & 18 & 26.1 & 3.9 & 180.6 & 7 & 151.7 & 12.3 & 13 & 2 \\
\hline Ceylan et al. 2018 [54] & CS & Turkey & Senior & $\mathrm{E}$ & 7 & 27 & 3 & 182 & 10 & 165 & 15 & 12.74 & 2.52 \\
\hline
\end{tabular}

Throws = number of throws completed during the test; Final HR = heart rate registered immediately after the test; HR 1 min. = heart rate obtained 1 min after the test; CS = cross-sectional study; $\mathrm{RM}=$ study with repeated measurements; $\mathrm{E}=$ elite; $\mathrm{N}$ = non-elite.

Table 2. Special Judo Fitness Test (SJFT) results reported in 17 international samples of junior male judo athletes.

\begin{tabular}{|c|c|c|c|c|c|c|c|c|c|c|c|c|c|}
\hline \multirow[b]{2}{*}{ Source } & \multirow[b]{2}{*}{ Study } & \multirow[b]{2}{*}{ Country } & \multirow[b]{2}{*}{ Age Category } & \multirow[b]{2}{*}{ Level } & \multirow[b]{2}{*}{$n$} & \multicolumn{2}{|c|}{ Throws } & \multicolumn{2}{|c|}{ Final HR $\left(b \cdot \min ^{-1}\right)$} & \multicolumn{2}{|c|}{ HR $1 \min \left(b \cdot \min ^{-1}\right)$} & \multicolumn{2}{|c|}{ SJFT Index } \\
\hline & & & & & & $\bar{x}$ & SD & $\bar{x}$ & SD & $\bar{x}$ & SD & $\bar{x}$ & SD \\
\hline Sterkowicz, 1997 [55] & CS & Poland & Junior & $\mathrm{N}$ & 11 & 24.5 & 1.8 & 176 & 14.5 & 130 & 20.7 & 12.55 & 1.18 \\
\hline Franchini et al. 2001 [39] & CS & Brazil & Junior & $\mathrm{N}$ & 6 & 25.3 & 2.6 & 193 & 5.5 & 167 & 7.8 & 14.26 & 1.85 \\
\hline Iredale et al. 2003 [56] & $\mathrm{RM}$ & New Zealand & Junior & $\mathrm{N}$ & 9 & 24.3 & 1.9 & 187.4 & 9.4 & 154 & 15.4 & 14.12 & 1.72 \\
\hline Khakhabrishvili et al. 2003 [40] & CS & Georgia & Junior & $\mathrm{E}$ & 7 & 25.4 & 0.3 & 188 & 0.5 & 162 & 0.5 & 14 & 0.22 \\
\hline Khakhabrishvili et al. 2003 [40] & CS & Poland & Junior & $\mathrm{E}$ & 7 & 24 & 0.3 & 177 & 0.4 & 154 & 0.4 & 13.86 & 0.14 \\
\hline Boguszewska et al. 2010 [11] & CS & Poland & Junior & E & 8 & 25 & 3.6 & 187 & 19.9 & 129 & 10.9 & 12.71 & 1.94 \\
\hline Mendes and Ferreira 2010 [57] & CS & Brazil & Junior & $\mathrm{N}$ & 8 & 22.7 & 3.4 & 182 & 8 & 155 & 15.6 & 15.23 & 2.94 \\
\hline Miarka et al. 2011 [18] & Control & Brazil & Junior & $\mathrm{N}$ & 8 & 23.7 & 1.4 & 187 & 11 & 154 & 11 & 14.49 & 1.3 \\
\hline Escobar-Molina et al. 2012 [31] & CS & Spain & Junior & E & 13 & 27 & 2 & 183 & 5 & 153 & 9 & 12.66 & 0.88 \\
\hline Barreto et al. 2012 [48] & CS & Brazil & Junior & $\mathrm{N}$ & 9 & 22 & 2.4 & 183.4 & 9.6 & 156.8 & 13.9 & 15.6 & 1.9 \\
\hline Sogabe et al. 2015 [24] & $\mathrm{RM}$ & Japan & Junior & $\mathrm{E}$ & 9 & 26.8 & 2 & 184.9 & 7.6 & 153 & 10.4 & 12.72 & 0.99 \\
\hline Simenko and Karpljuk 2016 [58] & $\mathrm{RM}$ & Slovenia & Junior & $\mathrm{N}$ & 9 & 22.11 & 1.83 & 191.22 & 6 & 163.89 & 12.05 & 16.17 & 1.63 \\
\hline Astley et al. 2017 [59] & Control & Brazil & Junior & $\mathrm{N}$ & 18 & 23.9 & 1.7 & 185.8 & 9.6 & 163.4 & 13.4 & 14.6 & 0.6 \\
\hline Courel-Ibanez et al. 2018 [60] & CS & Spain & Junior & $\mathrm{N}$ & 10 & 24 & 3 & 191 & 8 & 159 & 14 & 14.94 & 2.49 \\
\hline Courel-Ibanez et al. 2018 [60] & CS & Spain & Junior & $\mathrm{E}$ & 12 & 24 & 3 & 187 & 8 & 155 & 11 & 14.27 & 1.16 \\
\hline Agostinho et al. 2018 [61] & CS & Brazil, Spain, and Serbia & Junior & $\mathrm{E}$ & 45 & 27.4 & 2.7 & 180 & 11 & 156 & 17 & 12.35 & 1.36 \\
\hline Kons et al. 2018 [62] & CS & Brazil & Junior & $\mathrm{N}$ & 20 & 28 & 3 & 176 & 12 & 143 & 16 & 11.6 & 1.5 \\
\hline
\end{tabular}

Throws = number of throws completed during the test; Final HR = heart rate registered immediately after the test; HR 1 min = heart rate obtained 1 min after the test; CS = cross-sectional study; $\mathrm{RM}=$ study with repeated measurements; $\mathrm{E}=$ elite; $\mathrm{N}$ = non-elite. 


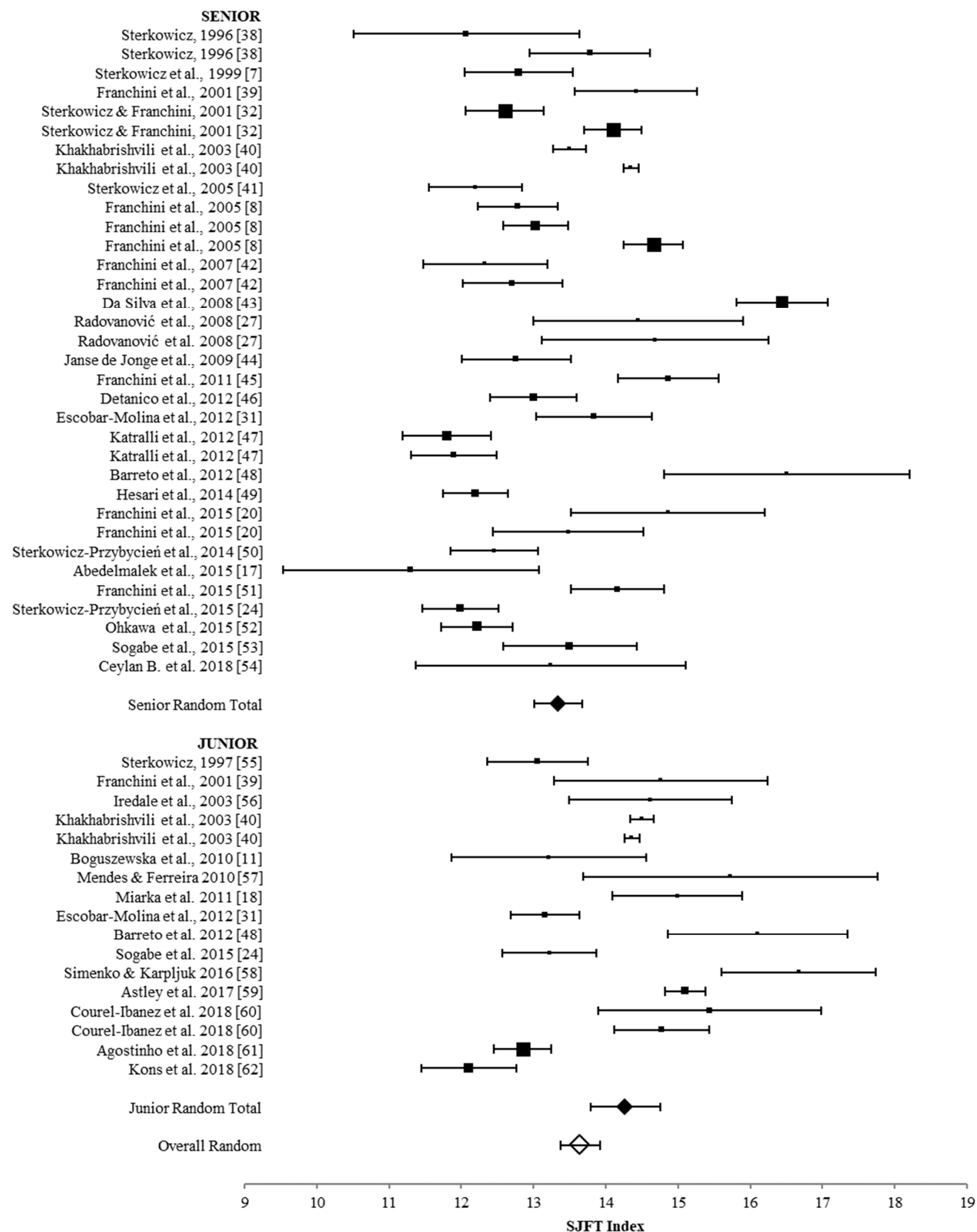

Figure 2. Forest plot summarizing the meta-analysis for Special Judo Fitness Test (SJFT) Index with mean values and $95 \%$ confidence intervals.

Medium effect sizes were identified for the age category comparisons in the SJFT index (Cohen's $d=0.38,95 \%$ confidence interval $(\mathrm{CI}=0.22$ to $0.54, p<0.001)$ and number of throws completed (Cohen's $d=0.41,95 \%$ confidence interval $(\mathrm{CI}=0.25$ to $0.57, p<0.001)$. A small effect size was identified for HR directly after the test (Cohen's $d=0.18,95 \%$ confidence interval ( $\mathrm{CI}=0.02$ to $0.35, p=0.025)$, while no effect was shown for HR 1 min after the test (Cohen's $d=0.001,95 \%$ confidence interval (CI $=-016$ to $0.16, p=0.994$ ) between the combined samples of senior and junior judo athletes. Data collected during the systematic literature review and meta-analysis allowed for the establishment of normative 
values for all of the SJFT variables. The classificatory data for senior and junior male judo athletes are presented in Table 3.

Table 3. Special Judo Fitness Test (SJFT) classificatory table for male judo athletes.

\begin{tabular}{ccccccccc}
\hline \multirow{2}{*}{ Classification } & \multicolumn{2}{c}{ Number of Throws } & \multicolumn{2}{c}{ Final HR $\mathbf{( b \cdot \mathbf { m i n } ^ { - 1 } )}$} & \multicolumn{2}{c}{ HR 1 min $\mathbf{( b \cdot \mathbf { m i n } ^ { - 1 } )}$} & \multicolumn{2}{c}{ SJFT Index } \\
\cline { 2 - 9 } & Junior & Senior & Junior & Senior & Junior & Senior & Junior & Senior \\
\hline Excellent & $\geq 29$ & $\geq 30$ & $\leq 165$ & $\leq 166$ & $\leq 129$ & $\leq 130$ & $\leq 11.04$ & $\leq 10.47$ \\
Good & $27-28$ & $28-29$ & $166-173$ & $167-173$ & $130-140$ & $131-141$ & $11.05-12.23$ & $10.48-11.68$ \\
Regular & $23-26$ & $24-27$ & $174-190$ & $174-188$ & $141-164$ & $142-163$ & $12.24-14.73$ & $11.69-14.22$ \\
Poor & $21-22$ & $22-23$ & $191-198$ & $189-195$ & $165-175$ & $164-173$ & $14.74-15.92$ & $14.23-15.43$ \\
Very poor & $\leq 20$ & $\leq 21$ & $\geq 199$ & $\geq 196$ & $\geq 176$ & $\geq 174$ & $\geq 15.93$ & $\geq 15.44$ \\
\hline
\end{tabular}

\section{Discussion}

The main goal of the present systematic review and meta-analysis was to develop a SJFT classificatory table for junior and senior male judo athletes. With this data, judo coaches and strength and conditioning professionals can use the age group classifications in the evaluation process of their athletes. The norms were different between age groups, with one throw more for seniors compared to juniors for all classifications. For HR immediately after the SJFT, lower values need to be achieved by junior judo athletes in order to be classified as Excellent; quite similar values are required for the Good classification, whereas higher values (i.e., inferior cardiovascular responses) characterize the Very poor, Poor and Regular classifications of junior compared to senior judo athletes. For HR 1-min after the SJFT, lower values should be achieved by junior judo athletes in order to be classified as Excellent and Very good, whereas a slower HR recovery characterizes the Very poor, Poor, and Regular classifications of junior compared to senior judo athletes. However, for the SJFT Index, senior judo athletes classifications are marked by lower values (i.e., better results) for senior compared to junior judo athletes. Moreover, it is important to emphasize that the differences between age groups reached medium effect sizes for the total number of throws and SJFT Index and a small effect size for the HR immediately after the test, whereas no effect was found for the HR 1 min after the SJFT.

Previous studies proposed SJFT classificatory tables for senior [14] and junior [61] judo athletes. The first investigation [14] used quintiles to divide the grades and had a broad range of judo athletes as subjects (141 athletes, from 16 to 34 years of age, with 51 up to $151.5 \mathrm{~kg}$ of body mass, 159 to $200 \mathrm{~cm}$ of height, and varying from 3rd kyu to $3 \mathrm{rd}$ dan). However, the classification established in that study resulted in lower limits for total number of throws in the Excellent and Good classifications; a similar value was found for the Regular classification, whereas the Poor and Very poor classifications had higher limits for the seniors in the present study. For juniors, similar limits were found in the present study compared to the table proposed by Franchini et al. [14].

For HR immediately after and one minute after the SJFT, our meta-analysis indicated that lower values characterized the Excellent and Good classifications for junior and senior judo athletes compared to the general table [14], whereas an overlap existed for the Regular and Poor classifications, and similar (for seniors) or slightly higher values (for juniors) were found for the Very poor classification. For the SJFT Index, lower values characterized the Excellent, Good, and Regular grades for seniors and the Excellent grade for juniors, whereas all other grades presented an overlap with the table proposed by Franchini et al. [14]. Taken together, these differences indicate that the present table resulted in the need for better performance in order to be classified as Excellent, whereas the reverse is true for the lower classification grades. This is likely due to the difference in percentile references used to develop each table with the current data being based on 5th percentile gradations at the extremes which better represent the best and worst SJFT performances.

Agostinho et al. [61] recently proposed a SJFT classificatory table for high-level junior judo athletes, using the same grade divisions used in the present study. In comparison, the newly developed table exhibits lower limit values for the Excellent, Good, Poor, and Very poor grades in total number of throws; higher values for the Excellent grade in HR immediately after the SJFT; higher values for the 
Excellent grade and lower values for the Very poor grade in HR one minute after the SJFT; and higher values for the Excellent, Poor, and Very poor grades in the SJFT Index. It is likely that these differences are due to the higher level and homogeneity of the judo athletes (i.e., National Team members) included in the Agostinho et al. [61] study compared to the heterogeneity of samples used in our meta-analysis.

A previous meta-analysis with female judo athletes also identified significantly lower SJFT Index values for seniors compared to juniors [30], although a larger difference between age groups was observed in the study with female athletes compared to the findings of the present investigation. The better performance for seniors compared to juniors can be explained by both greater training ages and the rigors of the national team selection processes. As maximal HR is inversely related with chronological age [63], higher values would be expected for juniors compared to seniors which is confirmed by the lower SJFT classification grades. HR recovery is influenced by several factors, but aerobic fitness seems to be a major contributor (i.e., aerobically-trained individuals present a faster HR recovery) [63]. However, no effect was found for HR one minute after the SJFT, suggesting that junior and senior judo athletes seem to present a similar aerobic fitness. Simultaneously, the SJFT index is correlated with parameters of both anaerobic (30-s Wingate test) and aerobic (graded exercise tests on treadmill) power and capacity, demonstrating the utility of this ecologically valid test that can be used to evaluate the effort tolerance in judo athletes when laboratory tests are not available [7]. Ceylan et al. [54] confirmed large positive correlations between SJFT results and the Wingate test in a group from the Turkish Olympic judo team along with large negative correlations with body fat percentage.

The SJFT is predominantly anaerobic in nature [45], and there is evidence that the total number of throws is related to the anaerobic fitness due to power generation necessary to execute judo throws as well as the required sprints between throws [29]. Consequently, any improvement in the total number of throws is related to an increase in at least a 6-m run (i.e., a minimum of $0.08 \mathrm{~m} / \mathrm{s}$ improvement in speed) and one throw during the test. Considering that the total duration of effort during the SJFT is $75 \mathrm{~s}$, and that during the test, athletes need to accelerate, decelerate, throw the opponent while changing direction, and accelerate again, an improvement in the total number of throws may be the result of increased speed, muscle power, and agility, either isolated or in combination. Furthermore, the number of throws completed during the SJFT has been shown to be related to technical effectiveness during judo competition, with differences depending on the length of the match and between men and women [62,64]. On the other hand, a lower HR after the SJFT or a faster HR recovery has been interpreted as an improvement in aerobic fitness [29]. Calculated from both of these sets of variables, the SJFT Index may be important for judo performance as many actions require use of the ATP-PCr, glycolytic, and oxidative energy systems [65].

While judo competitions are typically organized by weight category, the data identified during the systematic review process did not allow for the proper development of norms with respect to body mass. These limitations included the lack of reporting such details, the relative heterogeneity of the body masses represented within the literature (though sample data may be assumed to track with population data), and the potential for low sample sizes by weight category, particularly within the lightest and heaviest athletes. Future investigations may focus on expanding upon the current work by accumulating large-scale SJFT data from athletes in different weight categories.

\section{Conclusions}

The present study provides a comprehensive set of normative values for variables from the SJFT for junior and senior male judo athletes. Additionally, an age-group comparison was conducted with senior athletes, demonstrating a higher total number of throws (medium effect) and HR immediately after the SJFT (small effect), with limited differences observed for HR one minute after the SJFT between groups. Moreover, the SJFT index was lower for seniors compared to juniors (medium effect) indicating better overall performance during the SJFT by the more advanced athletes.

This work is dedicated to Professor Stanisław Sterkowicz, creative scientist and originator of the SJFT, who shared his passion for sport and served as a beacon for others. A man with 
an independent character, who sought innovative solutions and scientific investigations aimed at improving the practice of sport and coaching. He demonstrated how to connect the problems of theory, biomechanics, physiology, and psychology in the context of combat sports in an interdisciplinary manner. He maintained a collaboration with researchers from different countries and backgrounds for decades. He was the owner of black belts in judo, ju-jitsu, karate, and hapkido. Martial arts were his way of life.

Author Contributions: Conceptualization, Methodology, Formal analysis, and Funding acquisition, K.S.-P.; Writing - original draft preparation, Review and Editing, K.S.-P., D.H.F. and E.F.

Funding: This research was funded by project No. 192/BS/IS/2018, Statutory research, University of Physical Education, Kracow, Poland.

Conflicts of Interest: The authors declare no conflict of interest. The funders had no role in the design of the study; in the collection, analyses, or interpretation of data; in the writing of the manuscript, or in the decision to publish the results.

\section{References}

1. Sterkowicz, S. Test specjalnej sprawnosci ruchowej w judo. Antropomotoryka 1995, 12, 29-44.

2. Almansba, R.; Franchini, E.; Sterkowicz, S. An Uchi-komi with load, a physiological approach of a new special judo test proposal. Sci. Sports 2007, 22, 216-223. [CrossRef]

3. Santos, L.; González, V.; Iscar, M.; Brime, J.I; Fernandez-Rio, J.; Egocheaga, J.; Rodríguez, B.; Montoliu, M.A. A new individual and specific test to determine the aerobic-anaerobic transition zone (Santos Test) in competitive judokas. J. Strength Cond. Res. 2010, 24, 2419-2428. [CrossRef] [PubMed]

4. Lidor, R.; Melnik, Y.; Bilkevitz, A.; Arnon, M.; Falk, B. Measurement of talent in judo using a unique, judo-specific ability test. J. Sports Med. Phys. Fitness 2005, 45, 32-37. [PubMed]

5. Detanico, D.; Santos, S.G. dos Especific evaluation in judo: A review of methods. Rev. Bras. Cineantropometria E Desempenho Hum. 2012, 14, 738-748.

6. Kirkendall, D.R.; Gruber, J.J.; Johnson, R.E. Measurement and Evaluation for Physical Educators, 2nd ed.; Human Kinetics: Champaign, IL, USA, 1987; ISBN 978-0-87322-081-1.

7. Sterkowicz, S.; Żuchowicz, Z.; Kubica, R. Levels of anaerobic and aerobic capacity indices and results for the special fitness test in judo competitors. J. Hum. Kinet. 1999, 2, 115-135.

8. Franchini, E.; Takito, M.Y.; Kiss, M.A.P.D.M.; Sterkowicz, S. Physical fitness and anthropometrical differences between elite and non-elite judo players. Biol. Sport 2005, 22, 315-328.

9. Franchini, E.; de Moraes Bertuzzi, R.C.; Takito, M.Y.; Kiss, M.A.P.D.M. Effects of recovery type after a judo match on blood lactate and performance in specific and non-specific judo tasks. Eur. J. Appl. Physiol. 2009, 107, 377-383. [CrossRef] [PubMed]

10. Franchini, E.; Takito, M.Y.; Bertuzzi, R.C.M. Morphological, physiological and technical variablesin high-level college judoists. Arch. Budo 2005, 1, 1-7.

11. Boguszewska, K.; Boguszewski, D.; Buśko, K. Special Judo Fitness Test and biomechanics measurements as a way to control of physical fitness in young judoists. Arch. Budo 2010, 6, 205-208.

12. Sterkowicz-Przybycien, K.; Blecharz, J.; Sterkowicz, S.; Luczynska, A. Attention and acute judo-specific effort in athletes preparing for Olympic competition. Arch. Budo 2015, 11, 265-270.

13. Polski Związek Judo-Ogólnopolski Test Sprawności Motorycznej i Specjalnej Judo 2010; Testing in Polish Judo Association. Available online: http://www.judoinfo.pl/2010-01-30/polski-zwiazek-judo-ogolnopolskitest-sprawnosci-motorycznej-i-specjalnej-judo-2010 (accessed on 23 February 2013).

14. Franchini, E.; Vecchio, F.B.D.; Sterkowicz, S. A Special Judo Fitness Test Classificatory Table. Arch. Budo 2009, $5,127-129$.

15. Special Judo Fitness Test. Available online: http://smaes.archbudo.com/page/display/id/7/title/special-judofitness-test (accessed on 2 March 2019).

16. Franchini, E.; Matsushigue, K.; Kiss, M.A.P.D.M.; Sterkowicz, S. A case study of physiological and performance changes in female judô players preparing for the Pan-American Games. Rev. Bras. Ciênc. E Mov. 2001, 9, $21-27$. 
17. Abedelmalek, S.; Chtourou, H.; Souissi, N.; Tabka, Z. Caloric Restriction Effect on Proinflammatory Cytokines, Growth Hormone, and Steroid Hormone Concentrations during Exercise in Judokas. Oxid. Med. Cell. Longev. 2015, 2015, 809492. [CrossRef] [PubMed]

18. Miarka, B.; Del Vecchio, F.B.; Franchini, E. Acute effects and postactivation potentiation in the Special Judo Fitness Test. J. Strength Cond. Res. 2011, 25, 427-431. [CrossRef] [PubMed]

19. Radovanovic, D.; Bratic, M.; Nurkic, M.; Cvetkovic, T.; Ignjatovic, A.; Aleksandrovic, M. Oxidative stress biomarker response to concurrent strength and endurance training. Gen. Physiol. Biophys. 2009, 28 Spec No, 205-211.

20. Franchini, E.; Branco, B.M.; Agostinho, M.F.; Calmet, M.; Candau, R. Influence of linear and undulating strength periodization on physical fitness, physiological, and performance responses to simulated judo matches. J. Strength Cond. Res. 2015, 29, 358-367. [CrossRef] [PubMed]

21. Bonato, M.; Rampichini, S.; Ferrara, M.; Benedini, S.; Sbriccoli, P.; Merati, G.; Franchini, E.; La Torre, A. Aerobic training program for the enhancements of $\mathrm{HR}$ and VO2 off-kinetics in elite judo athletes. J. Sports Med. Phys. Fitness 2015, 55, 1277-1284.

22. Fukuda, D.H.; Stout, J.R.; Kendall, K.L.; Smith, A.E.; Wray, M.E.; Hetrick, R.P. The effects of tournament preparation on anthropometric and sport-specific performance measures in youth judo athletes. J. Strength Cond. Res. 2013, 27, 331-339. [CrossRef]

23. Agostinho, M.F.; Philippe, A.G.; Marcolino, G.S.; Pereira, E.R.; Busso, T.; Candau, R.B.; Franchini, E. Perceived training intensity and performance changes quantification in judo. J. Strength Cond. Res. 2015, 29, 1570-1577. [CrossRef]

24. Sogabe, A.; Sterkowicz-Przybycien, K.; Maehara, K.; Sasaki, T.; Sterkowicz, S. Effect of preferred body stance side on the performance of Special Judo Fitness Test in Japanese judo athletes. Arch. Budo 2015, 11, 1-6.

25. Sterkowicz, S.; Tyka, A.K.; Chwastowski, M.; Sterkowicz-Przybycień, K.; Tyka, A.; Klys, A. The effects of training and creatine malate supplementation during preparation period on physical capacity and special fitness in judo contestants. J. Int. Soc. Sports Nutr. 2012, 9, 1-8. [CrossRef] [PubMed]

26. Artioli, G.G.; Gualano, B.; Coelho, D.F.; Benatti, F.B.; Gailey, A.W.; Lancha, A.H. Does sodium-bicarbonate ingestion improve simulated judo performance? Int. J. Sport Nutr. Exerc. Metab. 2007, 17, 206-217. [CrossRef] [PubMed]

27. Radovanovic, D.; Bratic, M.; Milovanovic, D. Effects of creatine monohydrate supplementation and training on anaerobic capacity and body composition in judo. Acta Fac. Med. Naissensis 2008, 25, 115-120.

28. Lopes-Silva, J.P.; Felippe, L.J.C.; Silva-Cavalcante, M.D.; Bertuzzi, R.; Lima-Silva, A.E. Caffeine ingestion after rapid weight loss in judo athletes reduces perceived effort and increases plasma lactate concentration without improving performance. Nutrients 2014, 6, 2931-2945. [CrossRef]

29. Sterkowicz-Przybycień, K.L.; Fukuda, D.H.; Franchini, E.; Sterkowicz, S. Special Judo Fitness Test: Results and Applications. In Science and Medicine in Combat Sports; Drid, P., Ed.; Nova Science Publishers, Inc.: Hauppauge, NY, USA, 2017; pp. 145-173. ISBN 9781536100037.

30. Sterkowicz-Przybycień, K.L.; Fukuda, D.H. Establishing normative data for the special judo fitness test in female athletes using systematic review and meta-analysis. J. Strength Cond. Res. 2014, 28, 3585-3593. [CrossRef]

31. Escobar-Molina, R.; Huertas, J.; Gutierrez Garcia, C.; Franchini, E. Special judo fitness test performance of junior and Judo senior judo athletes from the Spanish Team. In Proceedings of the Game, Drama, Ritual in Martial Arts and Combat Sports, Genoa, Italy, 8-10 June 2012.

32. Sterkowicz, S.; Franchini, E. Specific fitness of elite and novice judoists. J. Hum. Kinet. 2001, 6, 81-98.

33. Moher, D.; Liberati, A.; Tetzlaff, J.; Altman, D.G. PRISMA Group Preferred reporting items for systematic reviews and meta-analyses: The PRISMA statement. PLoS Med. 2009, 6, e1000097. [CrossRef]

34. International Judo Federation. Sport and Organization Rules. Available online: http: //99e89a50309ad79ff91d-082b8fd5551e97bc65e327988b444396.r14.cf3.rackcdn.com/up/2018/10/IJF_ Sport_and_Organisation_Rul-1539980456.pdf (accessed on 13 October 2018).

35. Cohen, J. Statistical Power Analysis for the Behavioral Sciences; L. Erlbaum Associates: Hillsboro, NJ, USA, 1988.

36. Viechtbauer, W. Conducting meta-analyses in R with the metafor package. J. Stat. Softw. 2010, 36, 1-48. [CrossRef]

37. R Core Team. R: A Language and Environment for Statistical Computing; R Foundation for Statistical Computing: Vienna, Austria, 2016. 
38. Sterkowicz, S. W poszukiwaniu nowego testu specjalnej sprawności ruchowej w judo. Trening 1996, 12, 46-59.

39. Franchini, E.; Nakamura, F.Y.; Takito, M.Y.; Kiss, M.A.P.D.M.; Sterkowicz, S. A preliminary report of performance and blood lactate concentration after the Wingate test and a specific judo test. J. Hum. Kinet. 2001, 5, 109-119.

40. Khakhabrishvili, Z.; Akhalkaci, V.; Kvinikadze, D. Ispol'zovanie specificzeskich testow dla ocenki funkxionalnogo sostoiania borcov dziudo [Estimation of Functional State of Judokas with Special Tests Use]. Teor. Prakt. Fiz. Kult. 2003, 2, 36-37.

41. Sterkowicz, S.; Franchini, E.; Heinisch, H.D. Special Judo Fitness Test Performance in High Level Judo Players; International Judo Federation: Cairo, Egypt, 2005.

42. Franchini, E.; Nunes, A.V.; Moraes, J.M.; Del Vecchio, F.B. Physical fitness and anthropometrical profile of the Brazilian male judo team. J. Physiol. Anthropol. 2007, 26, 59-67. [CrossRef] [PubMed]

43. Da Silva, V.S.; Souza, I.; Bezerra, E.D. Avaliação de atletas de judô com a utilização do Special Judô Fitness Test (SJFT). Rev. Digit. B. Aires 2008, 13, 1-13.

44. Janse de Jonge, X.; Iredale, K.F.; Chapman, D.W. Responses to the Special Judo Fitness Test by Male and Female Members of the Australian Judo Team; Erasmus University: Rotterdam, The Netherlands, 2009.

45. Franchini, E.; Sterkowicz, S.; Szmatlan-Gabrys, U.; Gabrys, T.; Garnys, M. Energy system contributions to the special judo fitness test. Int. J. Sports Physiol. Perform. 2011, 6, 334-343. [CrossRef] [PubMed]

46. Detanico, D.; Dal Pupo, J.; Franchini, E.; Giovana dos Santos, S. Relationship of aerobic and neuromuscular indexes with specific actions in judo. Sci. Sports 2012, 27, 16-22. [CrossRef]

47. Katralli, J.; Goudar, S.S. Anthropometric Profile and Special Judo Fitness levels of Indian Judo Players. Asian J. Sports Med. 2012, 3, 113-118. [CrossRef] [PubMed]

48. Barreto, L.; Dos Santos Silva, R.; Valido, C.; Brito, C.J. Adaptation of Special Judo Fitness Test for Beginners. Arq. Cienc. Esporte 2012, 1, 2-6.

49. Farzaneh Hesari, A.; Mirzaei, B.; Mahdavi Ortakand, S.; Rabienejad, A.; Nikolaïdis, P.T. Relationship between aerobic and anaerobic power, and Special Judo Fitness Test (SJFT) in elite Iranian male judokas. Apunts Med. Esport 2014, 49, 25-29. [CrossRef]

50. Sterkowicz-Przybycien, K.; Szmatlan-Gabrys, U.; Gabrys, T.; Sterkowicz, S.; Ozimek, M. Effect of Throwing Method on Special Judo Fitness Test Performance in Competitive Period of Training. Life Sci. J. 2014, 11, 861-866.

51. Franchini, E.; Del Vecchio, F.B.; Ferreira Julio, U.; Matheus, L.; Candau, R. Specificity of performance adaptations to a periodized judo training program. Rev. Andal. Med. Deporte 2015, 8, 67-72. [CrossRef]

52. Ohkawa, Y.; Ishibashi, G.; Ozawa, Y. The Effects of Changing Throwing Techniques used in Special Judo Fitness Test in College Male Judo Players. Tokai Daigaku Keizaigakubu Kiyo 2015, 2, 6-11.

53. Sogabe, A.; Maehara, K.; Iwasaki, S.; Sterkowicz-Przybycien, K.; Sasaki, T.; Sterkowicz, S. Correlation analysis between Special Judo Fitness Test and Uchikomi Shuttle Run Rest. In Proceedings of the Archives of Budo Conference Proceedings, 1st World Congress on Health and Martial Arts in Interdisciplinary Approach, Częstochowa, Poland, 17-19 September 2015; pp. 119-123.

54. Ceylan, B.; Gurses, V.V.; Akgul, M.S.; Baydi, B.; Franchini, E. Anthropometric Profile, Wingate Performance and Special Judo Fitness Levels of Turkish Olympic Judo Athletes. Ido Mov. Cult. J. Martial Arts Anthropol. 2018, 18, 15-20.

55. Sterkowicz, S. Specjalna Sprawność Ruchowa w Judo; AWF: Katowice, Poland, 1997; pp. 188-194.

56. Iredale, F. Determining Reliability in a Judo Specific Fitness Test. In Proceedings of the World Judo Research Symposium, 3rd IJF Conference, Osaka, Japan, 9 September 2003.

57. Mendes, L.C.V.; Ferreira, C.E.S. Avaliação do componente aeróbio e anaeróbio em atletas da seleção estudantil de judô do distrito federal. Educ. Física Em Rev. 2010, 4, 1-6.

58. Šimenko, J.; Karpljuk, D. Can special judo fitness test be used to detect asymmetries in movement patterns? Homo Sport. 2016, 18, 14-17.

59. Astley, C.; Souza, D.; Polito, M. Acute Caffeine Ingestion on Performance in Young Judo Athletes. Pediatr. Exerc. Sci. 2017, 29, 336-340. [CrossRef]

60. Courel-Ibanez, J.; Franchini, E.; Escobar-Molina, R. Is the Special Judo Fitness Test Index discriminative during formative stages? Age and competitive level differences in U13 and U15 children. Mov. Cult. J. Martial Arts Anthropol. 2018, 18, 37-41. 
61. Agostinho, M.F.; Junior, J.A.O.; Stankovic, N.; Escobar-Molina, R.; Franchini, E. Comparison of special judo fitness test and dynamic and isometric judo chin-up tests' performance and classificatory tables' development for cadet and junior athletes. J. Exerc. Rehabil. 2018, 14, 244-252. [CrossRef]

62. Kons, R.L.; Franchini, E.; Detanico, D. Relationship between physical fitness, attacks and effectiveness in short- and long-duration judo matches. Int. J. Perform. Anal. Sport 2018, 18, 1024-1036. [CrossRef]

63. Kenney, W.L.; Wilmore, J.H.; Costill, D.L. Physiology of Sport and Exercise, 5th ed.; Human Kinetics: Champaign, IL, USA, 2011; ISBN 978-0-7360-9409-2.

64. Kons, R.; Ache-Dias, J.; Detanico, D. Can physical tests predict the technical-tactical performance during official judo competitions? Arch. Budo Sci. Martial Arts Extreme Sports 2017, 13, 143-151.

65. Franchini, E.; Artioli, G.G.; Brito, C.J. Judo combat: Time-motion analysis and physiology. Int. J. Perform. Anal. Sport 2013, 13, 624-641. [CrossRef]

(C) 2019 by the authors. Licensee MDPI, Basel, Switzerland. This article is an open access article distributed under the terms and conditions of the Creative Commons Attribution (CC BY) license (http://creativecommons.org/licenses/by/4.0/). 